PART 1

Conceptions of Childhood 
Nazan Çiçek - 9789004305809

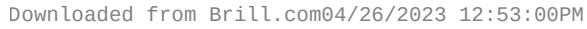
via free access 


\title{
The Interplay between Modernization and the Reconstruction of Childhood: Romantic Interpretations of the Child in Early Republican Era Popular Magazines, 1924-1950 ${ }^{1}$
}

\author{
Nazan Çiçek
}

Ahmet Haşim (1884-1933), the well-known Turkish poet and essayist, writing in Ikdam newspaper in 1928 used the approaching Christmas as an opportunity to contemplate the alleged 'deficiencies' of Turkish modernization. He criticized the Turkish upper classes' superficial interpretation of Westernization/modernization as conspicuous consumption and drew attention to the lack of a true understanding of the socio-cultural parameters that underpinned some Western rituals and manners. The Christmas holiday, an indisputably Christian festival, in its current form, Haşim believed, was a vehicle by which Western societies had come to demonstrate the value they attached to their children. As he expressed his discomfort with the Turkish society's 'indifference' towards children, Haşim ventured to urge the Kemalist founding cadres to introduce Christmas into Turkey as a children's festival in order to prove their dedication to the solution of the 'child question,' which indeed had been posing an enormous challenge to the young Republic:

The Christians' New Year's festival that they call Noël is approaching. All European newspapers and magazines are already flooded with advertisements for Noël gifts. Toy factories exhibit their new products in shops across the world. This festival is actually a children's festival. Father Noël [Santa Claus], namely Aya Nikola, will sneak down the chimneys on Noël morning and leave all sorts of presents for children. With the adoption of

1 This paper makes partial use of the findings of the research project “Geç Dönem Osmanlı ve Erken Dönem Cumhuriyette İnşa Edilen Toplumsal Cinsiyet Kategorilerinin Normallik/ İdeallik ve Anormallik/Ötekilik Kategorileri Üzerinden Analizi” [The Analysis of Gender Categories in the Late Ottoman and Early Republican Era with a Special Reference to the Manifestations of Normality/Idealness and Abnormality/Otherization], code number 10B5260002, sponsored by Ankara University, Research Projects Office. The project was conducted by Nazan Çiçek between 2010-2012. 
the Gregorian calendar, this festival, which in essence is by no means a religious festival, ought to have been established in our country too. Yet it merely turned out to be a new occasion for the fops living in luxurious apartments to dance and drink champagne, which is very regrettable. What we should do is to officially celebrate Noël as a children's festival. We have no particular hygiene regime, clothing, food, entertainment or playgrounds designed exclusively for children. We cannot claim that we are in the least interested in children's happiness. In order to grasp the meaning of children's happiness we have to observe the nations where children are loved and cared for. After all those novels, poems and plays we already adapted, would it fly in the face of our culture if we adapted the Noël festival for the sake of our children? ${ }^{2}$

As we know today, the Kemalists would opt to invent a children's festival to be celebrated on the 23 Nisan Bayrami, the foundation day of the Turkish National Assembly (April 23), rather than adapt Christmas in building their politicocultural symbolic repertoire as to childhood. This lengthy quotation from Ahmet Haşim's article, written only four years after the establishment of the new regime, is loaded with many-layered references to the matrix of modernization and rediscovery/reconstruction of the concept of childhood in Turkey in the early Republican era. In his usual straightforward yet witty manner Haşim reminds the Kemalist nationalist elites that modernization generates as well as dictates a new understanding of and approach to childhood, and that there is a strong connection and resonance between a nation's claim to modernization and its interest in children's happiness. His words simply yet clearly reflect the modern notion of childhood, which regards children as a distinct category in the life-cycle with special needs as well as an inherent "physical, social and structural vulnerability," ${ }^{3}$ who are by definition entitled to happiness.

As the literature on childhood firmly suggests, the concept of childhood is rather contingent and ever changing. As a social construction and "distinct from biological immaturity, childhood is neither a natural nor biological feature of human groups but appears as a specific structural and cultural component of many societies." It is reinvented or rediscovered as well as restructured

2 Ahmet Haşim, "Çocuklar İçin Bayram" [Festival for Children], İkdam, 11365, 12 Birincikanun, 1928, quoted in İnci Enginün and Zeynep Kerman (eds), Ahmet Haşim: Bütün Eserleri II (İstanbul: Dergâh Yayınları, 1991), 176-177.

3 Anneke Meyer, "The Moral Rhetoric of Childhood," Childhood, 14 (1), 2007, 85-104.

4 Alan Prout and Allison James, "A New Paradigm for the Sociology of Childhood? Provenance, Promise and Problems," in id. (eds), Constructing and Reconstructing Childhood (London: Routledge), 1990, 8. 
by each society over time in accordance with the prevailing worldwiews supporting those societies. ${ }^{5}$ What is also certain is that in tandem with the expansionist qualities and universalist claims of Western interpretations of modernity, a particular understanding of childhood that had been generated as a social and cultural construct of modern times in the Western world proved its hegemonic power in having an impact on the deconstruction and reconstruction of the idea of childhood in non-Western political landscapes with modernization agendas.

Philippe Ariès asserted in his L'Enfant et la vie familiale sous l'ancien régime, ${ }^{6}$ which laid the groundwork for the childhood studies in academia, that in modern times children, rather than being the transitory inhabitants of a Lilliputian world, came to be regarded as a sui generis group, separate from adults and deserving special treatment and care. From the mid-nineteenth century onward this modern notion, that saw childhood as "an ontology in its own right," also began, inter alia, to regard children as being "angelic creatures who have a natural goodness and clarity of vision that we might idolize as the source of all that is best in human nature,"7 and as living in a world of their own where innocence reigned: "[Children] in this Apollonian image, the formalization of which occurred with Rousseau's Émile, were not curbed nor beaten into submission but encouraged, enabled and facilitated." ${ }^{\text {Th }}$ They were expected to live in the world of childhood, untainted by corruption-a world, as Cunningham remarked, made up of "innocence, school, fun, games, friends, nature, and sweets."9 They were also kept away from the adult world of violence, sex, hard labour and politics. Also, towards the end of the nineteenth century in Western settings, especially for the middle classes, children's status as economic assets largely lost ground as their participation in the labour market became subject to officially imposed strict regulations and their association with domesticity and education gained impetus. Children gradually turned into emotional rather than financial investments for their parents, who through nostalgia and a romanticized envisioning of childhood as a 'Paradise Lost' sacralized childhood. Az Zelizer, investigating the changing patterns in

5 See William Kessen, Psychological Development from Infancy: Image to Intention (NewYork: Wiley, 1979); Anne-Marie Ambert, "An International Perspective on Parenting: Social Change and Social Constructs," Journal of Marriage and Family, 56, 1994, 529-543; Harry Hendrick, Childhood and English Society, 1880-1990 (Cambridge: Cambridge University Press, 1997).

6 Published in English as Philippe Ariès, A Social History of Family Life (London: Jonathan Cape, 1962).

7 Chris Jenks, Childhood (2nd edition, London: Routledge, 1996), 73.

8 Jenks, Childhood, 73.

9 Hugh Cunningham, Children and Childhood in Western Society since 1500 (London: Longman, 1995), 1. 
child labour, adoption and child-rearing practices at the turn of the nineteenth century and over the course of the twentieth in the United States, convincingly concludes that children shed their economic worth and began to acquire 'priceless' emotional value in modern times. ${ }^{10}$ As a result of their supposedly essential otherness and inherently vulnerable status, children increasingly became subject to an entirely different consumption regime that included the production of food, books, magazines, clothing, recreational spaces and living arrangements specially designed for them. In modern times childhood became highly commercialized in industrialized societies.

In the non-Western world, where "childhood was rediscovered and became a topic of broad intellectual inquiry;"11 at a time when "the validity of traditional models appeared to have crumbled,"12 modernizing elites increasingly tended to view the child question in the light of this modern Western conception of childhood, which in fact was by no means monolithic in itself. Yet informed by 'a post-colonial legacy,' the Western world, "through the Declaration of the Rights of the Child and the work of charitable agencies and international bodies in the Third World" exported one particular vision of childhood as correct childhood and engendered "the misguided and tacit assumption of a uniformity of childhood in Western Europe."13 Considering that the late Ottoman and early Republican Turkish modernizing elites took the Western world as their almost sole referential point, it was not surprising that they enthusiastically embraced this exported vision of 'correct childhood.' Thus in their eyes, as was suggested by the Western world, "the child symbolized all that is decent and caring about a society, it was the very index of a civilization." ${ }^{14}$ Aside from placing the child in the centre of their nation-building and citizen-creating project, they also tended to regard, at least discursively, the handling of children by society, in the broadest sense, as a benchmark in the progress of modernization and civilization.

As Deniz Kandiyoti correctly points out, "studies of modernization in Turkey have generally privileged the juridico-political and institutional realms," so that "comparatively little attention has been paid to the less tangible effects of

10 Viviana A. Zelizer, Pricing the Priceless Child: The Changing Social Value of Children (Princeton: Princeton University Press, 1985).

11 Anne Behnke Kinney, Representations of Childhood and Youth in Early China (Stanford: Stanford University Press, 2004), 2.

12 Catherine E. Pease, "Remembering the Taste of Melons: Modern Chinese Stories of Childhood," in Anne Behnke Kinney (ed.) Chinese Views of Childhood (Honolulu: University of Hawai'i Press, 1995), 287.

13 Jenks, Childhood, 122.

14 Ibid., 67. 
processes of social transformation on the emergence of new identities and forms of subjectivity." This has crippled "critical awareness of the specificities of the 'modern' in the Turkish context."15 As one of the specificities of the modern, the conceptualization of the child and childhood in Turkish Republican context in their own right has long been left unexplored. Some of the official institutions, such as Himaye-i Etfal [Children's Protection Society], or a series of state policies for education and indoctrination of Turkish children as part of the Kemalist nation-building strategies, have received some academic attention; ${ }^{16}$ yet the ways in which the concept of childhood in the cognitive map of the Republican modernizing elites was fashioned and conditioned by the modern notion of childhood that had been in progress in the Western world since Victorian times have not been subject to an in-depth analysis.

This study, by examining a body of essays on the subject of children and childhood that appeared in some popular magazines published during the formative years of the Republican regime (1923-1950), seeks to ascertain how and to what extent a particular interpretation of the modern notion of childhood informed, constituted and transformed the conceptualization of child and childhood in the minds of Turkish policy makers and pro-regime intelligentsia. The magazines under consideration are Süs (Ornament, 1923-1924), Asar-ı Nisvan [Women's Stories] (1925-1926), Ülkü [The Ideal] (1934-1948), Yedigün [Seven Days], (1935-1946) and Ev-Iş [House-Work], (1942-1950). With the exception of Ülkü, the

\footnotetext{
15 Deniz Kandiyoti, "Gendering the Modern: On Missing Dimensions in the Study of Turkish Modernity," in Sibel Bozdoğan and Reşat Kasaba (eds), Rethinking Modernity and National Identity in Turkey (Seattle: University of Washington Press, 1997), 113.
}

16 See Mustafa Şahin, “23 Nisan ve Himaye-i Etfal," [April 23 and Children's Protection Society] Toplumsal Tarih, Nisan [April], 1997 (40), 15-17; Kathryn Libal, "The Children's Protection Society: Nationalizing Child Welfare in Early Republican Turkey," New Perspectives on Turkey, 23, 2000, 53-78; Leyla Neyzi, "Object or Subject? Paradox of 'Youth' in Turkey," International Journal of Middle East Studies, 33 (3), 2001, 411-432; Yiğit Akın, Ana Hatları ile Cumhuriyet Döneminde Beden Terbiyesi ve Spor [Physical Education and Sports in the Early Republican Era] (İstanbul: İletişim, 2004); Füsun Üstel, Makbul Vatandaşın Peşinde: II. Meşrutiyetten Bugüne Vatandaşlık Eğitimi [In Quest of the Acceptable Citizen: Citizenship Education Since the Second Constitutional Era] (İstanbul: İletişim, 2004); Erhan G. Ersoy, "1930'ların Kültür ve Eğitim Anlayışının Çocuk Esirgeme Kurumu Neşriyatı Çocuk Dergisindeki Yansımaları," [The Reflections of 1930s Cultural and Educational Perceptions in the Children's Protection Society] Kebikeç 19, 2005, 373-387; Özge Ertem, The Republic's Children and Their Burdens in 1930 and 1940 s Turkey: The Idealized Middle-Class Children as the Future of the Nation and the Image of 'Poor' Children in Children's Periodicals (Unpublished MA Thesis, Boğaziçi University, 2005); Güven Gürkan Öztan, Türkiye'de Çocukluğun Politik İnşası [Political Construction of Childhood in Turkey] (İstanbul: İstanbul Bilgi Üniversitesi Yayınları, 2011). 
official publication of Halk Evleri [People's Houses], they were all published by private publishers and more often than not targeted a literate yet intellectually/ academically average female audience. When thoroughly examined, these magazines reveal many articles, editorials and comments on topics relating to children, ranging from pregnancy, childbirth, infant mortality, children's health and hygiene, to the centrality of children in population growth policies, parent-child relationships, pedagogy, the treatment of children at home and at school, educational and recreational practices devised for children and the importance of children for the future security and prosperity of the nation etc.-all of which attest to the growing interest in children as publicly recognized agents whose welfare is hailed as a national enterprise.

This study will focus on particular pieces that give insights into the construction of the child as a value in itself, rather than the already researched and documented issue of the child as a political, cultural or economic asset for the Turkish nation and the Republican regime. In other words, this study does not aim to portray the general imagery of the child and childhood as it appeared in the said magazines; neither does it attempt to provide a content and discourse analysis of those magazines with a special reference to the 'child issue.' It merely seeks to locate, identify and sample the manifestations of the Westernbased modern notion of childhood in the intellectual and discursive cosmos of the early Republican era through the investigation of some popular pro-regime magazines. The study is not as much interested in the representative quality of the examined magazines as in the fact that they published articles exemplifying the basic tenets of the modern Western conceptualization of childhood. The criterion in choosing the magazines used in this study, in other words, is rather random, other than the presumption that they were all constituted by the pro-regime intelligentsia for the consumption of average literate citizens, mostly women, waiting to be 'enlightened' on the requirements of the new modern social conduct, including child rearing.

Although it is very hard, if not almost impossible, to find an image of the Turkish child during the era that is not illustrated as the hope and sometimes as the very embodiment of the Turkish nation / the young Republic itself, there nevertheless exists a body of writing in those magazines that allows us to catch a glimpse of what the concepts of the child and childhood meant for those with cultural and symbolic capital in Bourdieusien sense in the early decades of the Turkish Republic. As they seek answers to questions such as 'what/who is a child?', 'how much should a child know about the evils and predicaments of the adult world?, 'how should parents punish or reward their children?' etc., these pieces reveal clues about the impact that the modern Western understanding of the child as well as the exported image of correct childhood had on the cognitive map of the Republican elites. 


\section{The Child as the Personification of the Nation and the Republic}

For the Kemalist elite the concept of childhood from the beginning served as a metaphor or a potent vehicle which represented/carried the spontaneity, joy, purity and naturalness of the Turkish Revolution and had notably positive connotations. What Catherine E. Pease asserts for the Chinese progressive intellectuals during the New Culture Period (1915-1921) also applies to the Kemalist founding elites: "Their interest in children and childhood was a natural outgrowth of the promotion of "newness" as a positive, indispensable value"17 which the Kemalists in fact had inherited from their Young Turk antecedents: ${ }^{18}$

17 Pease, Remembering the Taste, 280.

18 A formerly unprecented interest in the 'child issue' in the Turkish-speaking Muslim quarters of the Ottoman Empire first germinated in the late Tanzimat era (1839-1876) and became intensified during the periods of First and Second Constitutional Monarchy, including the long reign of Abdülhamid II between 1876 and 1909. This new interest manifested itself in the publication of numerous periodicals that were exclusively designed to be consumed by children. See Öztürk Emiroğlu, Tanzimattan 1928'e kadar Yayımlanan Çocuk Gazete ve Dergileri Üzerine BirInceleme [An Examination of the Children's Newspapers and Magazines Published Between the Tanzimat and change to: 1928] (Unpublished MA Thesis), Erciyes Üniversitesi, Kayseri, 1992. Those periodicals, essentially product of the modernization and centralization attempts of the Ottoman State that attributed special value to education as a vehicle of European modernity, were always highly prone to the dictates of the political regime of the time, and reflected and reproduced the main principles and ideas about society, power relations and official ideological stance that also characterized the prevailing educational system which was constantly under construction and reform. See Cüneyd Okay, Meşrutiyet Çocukları [Children of Constitutional Era], İstanbul, Bordo, 2000. Accordingly, while they aided the instutionalization of public schooling and functioned to discipline the spare time of students those periodicals championed and aimed to inculcate the principles of Ottomanism, Abdulhamid's Islamist flavoured conservatism and Constitutional Monarchy respectively. See Mehmet İnanç Özekmekçi, The Formation of Children in the Late Ottoman Empire: An Analysis Through the Periodicals for Children (1869-1914) (Unpublished MA Thesis, Boğaziçi University, İstanbul, 2005).

From the period of Abdulhamid II's reign onwards the 'social policies' of the Ottoman state began to put emphasis on the protection of poor and abandoned children. Three main institutions for the welfare of children, namely Darülaceze [poor house], Hamidiye Etfal Hastane-i Alisi [hospital for children] and Dar'ülhayr-ı Ali [orphanage], were founded by Abdülhamid II. See Özgür Sevgi Göral, The Child Question and Juvenile Delinquency During the Early Republican Era (Unpublished MA Thesis, Boğaziçi University, İstanbul, 2003), 41-42. The Young Turk era (1908-1918) whereby the constitutional monarchy was restored, saw a renewed enthusiasm with the 'child issue,' owing mostly to the increased efforts of the Committee of Union and Progress [CUP] in transforming the Empire into a highly centralized, standardized modern nation-state where children were hailed as the 
"The belief on the freshness of the child's perceptions and on the relative ease with which the child moves across traditional social barriers"19 helped them to associate the new regime with the concept of child and childhood.

The Turkish Republic was figuratively presented as a new-born child ${ }^{20}$ who had no (tainted and burdensome) past but only a promising future. Being young, and in particular being a child, was romanticized and became a discursive instrument that was used to underline the supposedly energetic, vigorous and youthful qualities of Turkish society and of its newly founded nation-state in contrast to the world's gerontocracies. This emphasis on the 'childishness' of the Republic, in another sense, was also employed to keep the self-improvability/

prospective regime defenders. Family as the nucleus of the society became the centre of attention and its reorganization and everyday practices were regarded as intrinsically linked to the new regime's success in creating new citizens. Turkish nationalism was also added to the educational agenda after defeat in the Balkan War in 1912. This time, not only the education of children but also their health, protection and entertainment became a topic of broad concern to the power-holders and intelligentsia. Himaye-i Etfal Cemiyeti, which would later be transformed into Çocuk Esirgeme Kurumu [Children's Protection Society] by the Kemalists, was first established in 1917 as a philantropic organization that aimed to provide shelter, food and protection for the abandoned and orphaned children of the Ottoman Empire. See Cüneyd Okay, Belgelerle Himaye-i Etfal Cemiyeti 1917-1923 [Himaye-i Etfal and the Related Documents 1917-1923] (İstanbul: Şule Yayınları, 1999) and Libal, "Children's Protection Society."

Turkish-speaking Muslim Ottoman elites gradually developed a discourse that attached profound importance to children, whose indoctrination as well as physical and mental well-being would guarantee the reproduction and future of the fatherland, the regime and the State. The Kemalists who took over the task that the Unionists had embarked upon, and whose hands were no longer fettered with the many internal and external entanglements of empire, gave full vent to their plan of creating and molding the children of Republic as they saw fit for the secular, Westernized and Turkish nation-state. For more on the Ottoman inheritance that the Kemalists worked upon, see Zafer Toprak, “İkinci Meşrutiyet Döneminde Paramiliter Gençlik Örgütleri”[Paramilitary Youth Organizations in the Second Constitution Period], in Tanzimattan Cumhuriyete Türkiye Ansiklopedisi (İstanbul: İletişim Yayınları, 1985), 531-536; Cüneyd Okay, Osmanlı Çocuk Hayatında Yenileşmeler 1850-19oo [Novelties in the Life of Ottoman Children 1850-1900] (İstanbul: Kırkambar Yayınları, 1998); Neyzi, “Object or Subject?.”

19 Pease, Remembering the Taste, 280.

20 This situation in fact was by no means peculiar to Turkey; as discussed by Pamela Karimi and Christiane Gruber, it also applied to almost the whole Middle Eastern region, where "at the dawn of Westernization and rapid infrastructural transformations, oftentimes an entire nation was personified as a child in need of special care and attention." See Pamela Karimi and Christiane Gruber, "Introduction: The Politics and Poetics of the Child Image in Muslim Contexts," Comparative Studies of South Asia, Africa and the Middle East, 32 (2), 2012, 276. 
revolutionary spirit alive by pointing at the importance of remaining in touch with one's/a nation's 'inner-child,' characterized by its capacity for unrestrained emotion, directness and self-forgetfulness. ${ }^{21}$

The child for the Kemalist elite, in other words, allegorically stood for the Turkish Republic as well as the Turkish nation. This allegory was constituted both visually and discursively in many texts representative of the zeitgeist of the early Republic. As Yasemin Gencer, drawing on her analysis of pro-Kemalist political cartoons published during 1923-1928, displays, the Republic was depicted in its first anniversary as a toddler practising its first steps, in its fifth anniversary and as a five-year-old learning to write and read:

The most prominent image [in these cartoons] is that of the child, which alternatively can represent the young Republic, the innocent nation, or future generations of the Turkish people. [...] The child's liminal status as a link between past ancestral achievements and future transformation was exploited to present nationalist belief in the continuity and persistence of the solidary nation. ${ }^{22}$

Thus, the child was by no means just a child in the early Republican Turkish political landscape. In a highly pragmatical discursive cosmos in which everything was judged and assessed through its contribution to the success of the new regime, the value attached to the child was inextricably linked to the potential services it would provide for the well-being of the nation. The politically constructed image of the child as the Republic's active citizen in the future overrode the image of the child acquiring value in and of itself. Children were placed in the centre of nation- and state-building policies. An article by Burhan Asaf, ironically titled "The Love for Children," summarizes the way in which Turkish children were instrumentalized by the Republican regime:

21 In a similar vein, Njabula Ndebele, talking about the South African National Reconstruction, explains the inextricable link between recovery of childhood and innocence and the reconstruction of South African society. Ndebele emphasizes the symbolic value of children's energy, fearlessness and questioning attitude as the essential prerequisites for building a new society. See Njabulo Ndebele, "Recovering Childhood: Children in South African National Reconstruction," in Sharon Stephens (ed.), Children and the Politics of Culture (Princeton: Princeton University Press), 1995, 321-333.

22 Yasemin Gencer, "We Are Family: The Child and Modern Nationhood in Early Turkish Republican Cartoons (1923-28)," Comparative Studies of South Asia, Africa and the Middle East, $3^{2}$ (2), 2012, 295-296. 
Today, we are capable of comprehending the true meaning of society, economics, welfare, population and state. This allows us to approach the child issue as a particular cause. Yet we do not believe in pursuing a child cause per se, we believe that we should treat the child issue as part of a greater cause. We are realist people. There is only one great cause we strive for and that is the Turkish revolution. Everything we do is being done for the sake of this revolution. All our acts are inspired by and serve the ends of this revolution. It is our only yardstick and only principle. This also applies to our dealings with the child. The Turkish child will be assessed and handled through the requirements of this revolution. In the light of the ideals of the revolution the child will acquire its new meaning and status. The child's value and importance will be determined by its relationships with the objectives of the revolution. ${ }^{23}$

As a result, the concept of the child was reconstructed and furnished with a powerful symbolic value which in turn overburdened actual Turkish children with many responsibilities and duties, and who had to prove that they were worthy of the hopes set upon them by the new regime.

The Kemalist cadres, claiming an ontological fracture between the Ottoman Empire and the Republic, and undertaking a project of re-habituating the nation along Western lines, took on a paternal disposition with its adult population, "whose mind and memory were tainted with the unwanted residue of the past times," ${ }^{24}$ and infantilized them through a large-scale mobilization campaign that was designed to disseminate modern ideas and methods for the treatment of children. The Republican regime, now replacing the former Islamic-Ottoman regulations of the body and social space and constructing a new normative order, believed that the traditional way of handling children was not good enough, and perhaps even harmful, for raising healthy, sturdy, intelligent and patriotic citizens. This meant that the Turkish state set out to act as parens patriare for the children of the nation until they themselves reached reproductive age. The state positing the familial sphere as a site of constant intervention for the common good of the nation sought to teach current parents the proper ways of child rearing, which loomed large from scientific breast

23 Burhan Asaf, "Çocuk Sevgisi," no date or publication name, quoted in Ertem, The Republic's Children, 2005, 1. Ertem explains that she obtained the material from Cüneyd Okay's private archive and that the article had been published in a supplement to a journal or magazine, the name of which did not appear on the supplement. She believes that the article dates from sometime before 1935 .

24 Öztan, Türkiye'de Çocukluğun, 7. 
feeding to hygiene, how to discipline and affection. Gürbüz Türk Çocuğu [Robust Turkish Child] commented in 1930:

the new generation [would] create a new society, yet the family [was] old. It owe[d] its power to the institutions dating back to the old ages. Left alone, the family [would] not be, in any way, able to bring up and educate the child of the new generation. ${ }^{25}$

As Sadi Irmak MD (1904-1990), a prominent figure of the Kemalist era, flatly asserted in $\ddot{U} l k \ddot{u}$ in 1944, although the regime did not regard the child as a public commodity that should be taken away from its parents, it nevertheless did not think that the child and its destiny should be left completely to the hands of its parents. The child was too precious and important for the regime and society for parents to be allowed to raise it according to their own preferences. The child stood at the centre of both the population growth policy and the nation-building and modernization efforts:

If the Turkishness shall reign over this territory, if the Turkish language shall be spoken eternally, if the Turkish nation shall prosper and flourish, then we have to pay utmost attention to the child, providing it with love, care and protection, following its trajectory of progress carefully and controlling its process of growing up closely. ${ }^{26}$

Again, this was by no means peculiar to Turkey and the Kemalist cadres. During periods of nation building, children and their upbringing had always been a main concern for nationalist elites. Anne Scott MacLeod explains how in the early nineteenth century, when the American Republic was still young, concern for the future of the new nation and for children became thoroughly intertwined:

Together, these preoccupations produced a flood of advice literature for parents and instructive fiction for children, most of which said nearly identical things about ideal child management, on the one hand, and ideal child behaviour, on the other. Both literatures were prescriptive, the fiction no less than the advice books, and the prescriptions were quite

25 “İstismar Edilen Çocuk," [The Child that is Abused] Gürbüz Türk Çocuğu, 43, Nisan [April], 1930, 7, quoted in Pınar Öztamur, Defining a Population:Women and Children in Early Republican Turkey 1923-1950 (Unpublished MA Thesis, Bosphorus University, İstanbul, 2004), 29.

26 Sadi Irmak, "Çocuk ve Meseleleri" [Child and the Child Question], Ülkü Halk Evleri Mecmuası, 23, 1944, 3. 
remarkably consistent. The image of the well-managed child and of the ideal home that was to produce him or her shine forth everywhere in the admonitory writing of the new American Republic. ${ }^{27}$

As the Kemalists worked their way into constructing their modern conception of the child and formulating their vision of modern childhood, they often stigmatized 'the Other,' namely the non-modern interpretations of childhood and treatments of children that were invariably represented by Eastern and by implication Ottoman and Islamic forms of conduct with children. This constant "reference to an assumed prior state that was defective and in need of reform, regardless of whether the patterns in question actually obtained in the society," ${ }^{28}$ was an expected outcome of the Kemalist attempts at articulating a new regulatory discourse, as was the case with all regulatory discourses. An article from Cumhuriyet Çocuğu, a fine example of the body of children's magazines that proliferated in 1930s Turkey, illustrates the alteritist discourse exploited by the new regime in the reconstruction of Republican, and hence 'modern,' conceptualization of childhood:

In the beginning the Ottoman Turks appreciated children and endowed them with rights and freedoms just as the Huns had done before them. But in time the despotic Ottoman Sultans and governments slowly corrupted social life through their backward rules. The best features of the Turkish tradition were ignored. The child too lost its value. The Ottoman child became an encumbrance, an overcrowding. It was destitute of all sorts of rights, regularly beaten and insulted. [...] The child in the Ottoman Empire pursued a very hard life until the collapse of the Ottoman rule. You, the future adults of the republic, there is no need to remind you how happy and sheltered your life is now. ${ }^{29}$

Parenting, especially motherhood, as the most crucial space in child rearing came under close scrutiny. As Pınar Öztamur demonstrates, "with the advent

27 Anne Scott MacLeod, American Childhood: Essays on Children's Literature on the Nineteenth and Twentieth Centuries (Athens: University of Georgia Press), 1994, 99.

28 Kandiyoti, Gendering the Modern, 117.

29 Cumhuriyet Çocuğu Öğretmeni, "Tarihten Yapraklar, Türk Tarihinde Çocuk," Cumhuriyet Çocuğu, 26, 1938, 473. Özge Ertem supplies several other examples in the same vein which openly constrast the Republican "loving and caring" treatment of children with the "inconsiderate, even inhumane" Ottoman attitudes towards children. See Ertem, The Republic's Children, 53 n. 82. 
of a modernizing discourse, child-rearing became embedded almost exclusively in the sphere of mothers" who were expected to produce "physically, mentally and morally healthy children" in accordance with "the desired modern, rational and hygienic principles." ${ }^{30}$ During the early years of the Republic the popular women's magazines often published articles focusing on motherhood which referred to women as "meta-human creatures" and "the architects of the new society who would secure its future well-being by giving birth to new generations, as well as undertaking their early socialization." ${ }^{31}$ Various texts depicting 'perfect motherhood' and correcting the false beliefs or harmful practices in child-rearing that should be abandoned were published. As Aylin Özman argues in her work on Vâlâ Nureddin, aka Vâ-Nû (1901-1967), a well-known Turkish author and journalist (and a prolific mouthpiece of Kemalist modernization project), "the modernization of motherhood," which inevitably included the modernization of childhood, "was regarded as instrumental for the Europeanization of the country." The "major point that [Vâ-Nû] criticize[d] [was] the dominance of Eastern values and modes of behaviour in most mothers' attitudes towards their children."32

By and large, the treatment of children was seen as a litmus test for the Republic's march along the path of modernization and Europeanization. Attempts at incorporating the modern child-rearing practices imported from the Western world into the realm of Turkish childhood and constructing a new understanding of the child and childhood informed by the modern notion of childhood were mutually constitutive in the Turkish case. Although the emphasis was mostly and ineluctably on the rediscovered and indispensable value of the child for the future of the nation and the Republican regime, the child as a value in itself (and childhood as an ontology in its own right), and whose characteristics, singularities and needs distinguished it from the adults, was also of interest to some Turkish intelligentsia. If Turkish children were to be raised through modern methods of hygiene, health, nurture and pedagogy, then they had to be understood, perceived and defined through the parameters of the modern notion of childhood. And when the child was once seen through the prism of the modern notion of childhood it was only self-evident that it

30 Öztamur, Defining a Population, 26.

31 Aylin Özman, "Domesticated Souls: Vâlâ Nureddin (Vâ-Nû) on Womanhood," Turkish Studies, 8 (1), 2007, 141.

Ibid. 
had to be handled through modern child-rearing practices. Considering the definition of what a child is maps out the complex topography of childhood in which children are treated in a particular society and time; and the body of advice literature with respect to modern child rearing that became omnipresent in popular (especially women's) magazines during the early decades of the Republic stood in testimony to the impact that the modern notion of childhood had on the conceptualization of the child and childhood in the mind of the Turkish Republican elites.

\section{What is a Child and How to Treat It? The Definition and Perception of the Child and Childhood in Early Republican Magazines}

What distinguished the modern interpretation of childhood was the fact that it approached childhood as a definite stage apart and children as a sui generis category intrinsically different from adults and who should be seen and treated in a way acknowledging their essential otherness. Yet this did not necessarily mean that the modern notion of childhood professed one single perception of the child and childhood that remained unchanged over time. On the contrary, from the very beginning it harboured many competing ideas as to the 'nature' of the child as an entity in its own right which vied for a place in the construction of modern childhood. In many cases those ideas were not mutually exclusive and in fact mostly coexisted, constantly constituting one another. Each approach generated its own set of parenting rules in accordance with its conceptualization of the child. Calvinist and Evangelical approaches, acting on the assumption of children's inborn sinful, pre-social, primitive and hence dangerous nature prescribed strict control and discipline, including corporal punishment, in order to create conformable adults. Although Rousseau's Émile $(1762)$ presents an alternative to purging the child from its original sin, Evangelical parenting nevertheless held sway for a long while until Romanticism gained hegemony from the mid-nineteenth century, finally paving the way to the child-centred societies of the twentieth century.

Thus over centuries the modern notion of childhood went through specific phases under the influence of many movements and thinkers, from Puritanism to Locke and Rousseau to Romanticism, as the pendulum of the modern comprehension of childhood swung between the images of the child as savage and the child as angel to differing degrees (or between Dionysian child and Apollonian child, as Jenks termed it. ${ }^{33}$ ) Accordingly, the modern notion of childhood did not

Jenks, Childhood, 70-78. 
represent a monolithic understanding or actual experience of childhood in modern Western societies that could offer ready-made models and clear-cut policy solutions. Nevertheless, at the beginning of the twentieth century there was a Western blueprint that purported to describe the true and correct modern childhood which modernizing elites, decision-makers and intelligentsia in nonWestern geographies (who, more often than not, were very much interwoven with one another) were willing to grasp. Kemalist politico-bureaucratic elites and pro-regime intellectuals for whom Western modernity provided the main point of reference tended to prioritize a particular image and perception of the child and childhood constructed in the Western world, which they believed epitomized the proper and most modern approach to the child issue. This was an image that had been largely fashioned both by Romanticism and also by what Carolyn Steedman identifies as a "central tenet of nineteenth-century reforming liberalism," referring to the measurement of a society's civilization and progress "through its treatment of disadvantaged and dispossessed groups such as women, slaves and children." ${ }^{44}$ The Turkish Republic's founding elites thus perceived a 'model childhood' that should be embraced and emulated as a part of modernization, with children portrayed as innocent and vulnerable beings who should be protected and enabled, and childhood as a privileged time in the lifecycle that should be worshipped and lengthened as long as possible.

The early Republican-era magazines under examination reveal instructive clues as to the discursive power that childhood innocence as an essential component of modern childhood enjoyed in the cognitive map of the Turkish intelligentsia. Some of the articles that refer to the innocence of children make a point emphasizing that although innocence is a trait that cuts across all children, it is, nonetheless, the modern Western world that recognizes and values childhood innocence most. An article in Süs Magazine in 1924 on family life in Britain written by Abdullah Cevdet (1869-1932), a well-known politician and thinker with extreme pro-Western tendencies, makes a brief comparison between British — and by implication European—and Turkish attitudes towards childhood, overtly favouring the former over the latter. The article also unmistakably mirrors the romantic maxim that a "child's sojourn in childhood was to be protected, not hastened": ${ }^{35}$

The child maintains its innocence for a long time because innocence is embedded in its nature. The precocious child, the kind that we call grown 
up before its time, is almost unheard of in Britain. Paring up the childhood years is an attempt to shorten the longevity of human life. The British regard childhood, the magical time in life cycle, as an astonishing opportunity bequeathed to human beings. ${ }^{36}$

A year later, another article in Asar-ı Nisvan, ascertaining whether children should be allowed to read newspapers, reproduces one of the basic principles of the modern notion of childhood, which dictates that in order to retain and foster childhood innocence, children should be kept away from adult matters, and that their access to some sort of knowledge and experience should be curtailed. Instead they should be provided with material that fits their needs and feeds into their supposed innocence:

Children's literature has not yet become widespread in our country. All there is for our children to read is the novels, stories and magazines produced for adults. I doubt that any parent in our society has seriously thought about the harmful effects those kinds of reading material may cause to their children. Likewise not many of us are concerned about whether newspapers should be allowed to children. If we spare some time to think about it, it seems obvious that no parent would be willing to permit their children, whom they love so dearly and strive so adamantly to protect from the dangers and damages of life, to read newspapers. Can compassionate and serious parents possibly wish their children to be exposed to the bitter, atrocious, abhorrent realities of life as well as scary and confusing political issues and conflicts that they even themselves would rather stay away from in the form of newspaper? ${ }^{37}$

As Fletcher points out, Romanticism meant that childhood began to be sentimentalized in the Victorian period:

[It] became a special time, the best of times, a time that was sanctified. Thus the Romantics, with their emphasis upon the child as 'father to the man,' extended selfhood backwards into childhood. ${ }^{38}$

36 Abdullah Cevdet, “Ingiltere'de Aile Hayatı"[Family Life in England], Süs, 49, 17 Mayıs [May], 1340 [1924], 1.

37 K.A., "Çocuklarımız Gazete Okumalı mı? Etfalin Terbiye-i Ruhaniyesi" [Should Our Children Read Newspapers? Psychological Training of our Small Children], Asar-ı Nisvan, 8, Haziran [June] 1, 1341 [1925], 6-7.

38 Anthony Fletcher, Growing Up in England: The Experience of Childhood 1600-1914 (New Haven: Yale University Press), 2008, 10. 
The beginning of the twentieth century saw the apogee of the romanticization of childhood in the Western world. In the United States, for example,

at the popular level, the romantic outlook was sentimental, dwelling on children's beauty and innocence. At the aesthetic level, romanticism went farther, surrounding childhood with an aura of myth, seeing in children the elemental qualities of nature unspoiled. ${ }^{39}$

An article that appeared in Yedigün in 1934 displays how the modern notion of childhood, with clearly discernible romantic undertones, had become the main source of inspiration as well as the sole referential framework in the proregime elites' approach to the 'child question.' The article, delving into the Republic's celebrations of the children's festival on 23 Nisan Bayramı-which itself stands as a monumental reminder of the Kemalist regime's discursive devotion to the supposed importance and value of children-bears all the distinctive marks of romanticized interpretation of modern childhood. It also condemns pre-modern, and hence 'un-civilized,' attitudes towards children, hinting at the correlation between human progress and the rising status of children in modern societies:

The child is a world in its own right with many marvels. Previous generations with their old-fashioned ideas found it unnecessary to unveil the mysteries of that complicated yet fascinating world. Yet today's enlightened pedagogues devote all their time and energy to untie the knots of this enigma. The child, who used to live like a weed, is being treated as a rare and precious plant at the hands of today's powerful nations. ${ }^{40}$

A year later and again in honour of the children's festival, Yedigün published another article which, in line with the romantic assumption that "childhood was the high point of life" and that "the road to maturity was not an upward progress, but a descent," ${ }^{41}$ mourned for the loss of childhood:

We always look down on children, thinking that we are superior to them. This in fact happens to be only our imagination. We usually believe that children are subject to us, yet we are deeply mistaken. We cannot reign over children. The only thing we can do, however, is to admire, envy and

39 MacLeod, American Childhood, 117.

40 “Çocuğun ve Annenin Bayramı" [Children's and Mothers' Festival], Yedigün, 59, 25 Nisan [April], 1934, 4.

41 MacLeod, American Childhood, 156. 
appreciate children. Each and every child owns a treasure that we ourselves lost as we grew up. We adults seem very impoverished compared to the wealth children have in themselves. [...] The child does not know anything about the realities of life. The reality of life as we adults call it is nothing other than the ache and hurt we feel in our heart. The reality of life is the residue left by the days, months and years that constantly pain our soul. Our knowledge of the realities of life hardly entitles us to boast about ourselves and belittle children. ${ }^{42}$

In the same issue, Hüseyin Cahit Yalçın (1875-1957), a famous figure in the political panorama of the late Ottoman and early Republican era, openly associated childhood with happiness, which he saw as a children's right. "Joy," he wrote, "is children's prerogative," adding that "they have the right to not worry about anything and be happy at least during their childhood." 43

In 1945 a piece appeared in $\ddot{U} l k \ddot{u}$ - the official publication of Halk Evleri [People's Houses], which the Kemalist cadres had founded to teach the populace modern conduct as well as the regime's fundamental values-showing that the modern notion of childhood seems to have entrenched itself in the minds of the Republican intelligentsia. Echoing very much Rousseau's Émile, which had called for the child to be allowed to discover the secret of happiness for itself, the article shows all the signs of the hegemonic twentieth-century Western discourse of childhood:

When we assess children's drawings we should avoid judging them according to our own measures and tastes. We adults can learn from children because they are a value in their own right. We should allow children to express and fulfil themselves freely. And the first prerequisite of this is to attach value to children for merely being children and believe in their abilities. ${ }^{44}$

Considering "parenting is constantly being constructed according to the ideologies and the paradigms of those sciences and professions that happen to dominate at any point in time in terms of dictating what is good for children,"45 it is not surprising to see that the popular magazines under examination often

\footnotetext{
42 Selami İzzet Kayacan, "Çocuk” [The Child], Yedigün, 111, 24 Nisan, 1935, 14-15.

43 Hüseyin Cahit Yalçın, "Çocuk Haftası" [Children's Week], Yedigün, 111, 24 Nisan, 1935, 4.

44 Cemal Bingöl, "Çocuk Resimleri ve Yetişkinler” [Children's Drawings and Adults], Ülkü, 26, 1 Ekim [October], 1945, 15-16.

45 Ambert, "International Perspective," 530.
} 
passed opinions on modern parenting as they discussed the meaning and value of the child. At the beginning of the twentieth century parenting as part of the biopolitics of modernization was becoming heavily medicalized, psychologized and psychiatrized. In the Western world, advice literature preaching scientific child-rearing practices was burgeoning: parents were admonished to employ scientific methods provided by modern medicine in their dealings with children, be it relating to bowel movements, the correct temperature for bath water or how to deal with tantrums. As mentioned earlier, the health of Turkish children was a grave concern for the Republican elites, since their healthy, sturdy bodies were regarded as the most tangible testament to the well-being of society as well as the efficiency of the new regime, and this was coupled with the Kemalist elites' eager aspirations to catch up with Europe. Consequently, advice literature invariably informed by "scientific European pedagogy" covering every aspect of parenting and describing acceptable and ideal forms of child rearing similarly proliferated during the early decades of the Republic. The magazines under examination provide many informative examples of that literature which cannot be reproduced within the scope of this study. Nevertheless, some articles are worth mentioning in that they manifest the intricate relationships that played out between biopolitics, modernization, the reconstruction of childhood and parenthood, and nation-building in Turkish Republican context. One article from 1949, entitled "Are You a Good Mother?" encapsulates all the parameters that the modernizing elites wished to dominate in the newly devised normative space regulating childhood and parenthood:

An ideal and knowledgeable mother breast-feeds her infant. She sometimes ignores tantrums in order not to spoil the child. After weaning the child she keeps it in her room but in a separate bed, and later transfers the child to another room. She never allows the child to sleep over at someone else's house, not even in the house of close relatives. She has the child examined by a doctor regularly even if there are no health problems with the child. She never beats the child. A good mother supervises her child in choosing friends, keeps in constant touch with his/her teachers, shows concern over the child's interests and talents. She never harms the child's natural innocence by terrifying and coercive acts. A good mother ascertains the good and bad traits in her child's character and helps the child develop the former and rehabilitate the latter. A good mother knows that she sometimes needs to restrain her motherly instincts and sacrifice her clemency for the sake of child's discipline. ${ }^{46}$ 
Peter Stearns, in his Childhood in World History, observed that the sentimental Victorian conceptualization of childhood as 'loving innocence,' which prepared for the child-centred society of the twentieth century, unprecedentedly increased "parental, and particularly maternal responsibilities in protecting children from corruption as well as ill-health" and that "many women worked very hard to maintain a sunny disposition with their offspring." ${ }^{27}$ Likewise, Anne Scott MacLeod detects a consensus at the beginning of the twentieth century in middle-class American culture which approached childhood as a time for happiness, "a season in the sun before the shadow of adult responsibility fell." Thus "children were integral parts of their families, yet a child lived at a little distance from the serious concern of adult life." ${ }^{\prime 4}$ An article published in $E v$-Is ş magazine in 1942 by Kemalettin Tuğcu (1902-1996), a famous children's books writer, appears as an epitome of the conduct literature, disseminating the Western middle-class idea of protective parenting to Turkish mothers:

Given that they are not capable of contributing to the household income, what is the point of letting children know about our economic dire straits and the deprivations of our family life that are bound to cause sorrow in their young minds and hearts? The life you are living is your life with its all fortunes and misfortunes. You are the ones who should take responsibility and struggle for a better life. Your children should know only about the good and pleasant parts of life and be sheltered from the cruel and unpleasant parts. Otherwise they lose their hope for future. In order to be able to keep children away from the distressing sides of our family life we should limit their contact with the adult members of the family and provide them with a room of their own. You should treat your children as though they are privileged guests in your house who do not have to know about the agonizing and distasteful features of your household. ${ }^{49}$

Raising sheltered children in a bubble, so to speak, also called for the abandonment of all sorts of violent acts by parents, be it corporal punishment, tyrannical control or denigrating rebukes. Since Victorian times, advice literature in the Western world had been urging parents to discipline their children through love and considerate care rather than physical pain. As vigorously asserted in Melesina Trench's Thoughts on Education (1837), "beating children produced

\footnotetext{
47 Peter N. Stearns, Childhood in World History (London: Routledge, 2006), 60.

48 MacLeod, American Childhood, 167.

49 K. Tuğcu, “Çocuk Terbiyesi: Büyükler ve Küçükler” [Children’s Education: Adults and Kids], Ev-Işs, Temmuz [July], 1942, 68.
} 
pusillanimity or hardness, cruelty, obstinacy," and "chastisement, however applied, whether spanking, caning, slapping, ear-pulling, hair-dragging or any other uncouth and barbarous shape would never produce good." ${ }^{50}$ As home increasingly came to be seen as a haven of love, especially for the middle classes, training children at home through corporal punishment gradually lost its legitimacy. In the highly psychologized milieu of the twentieth-century parenting, alongside beating, verbally harsh treatment of children was also added to the list of unacceptables. A piece published in Yedigün in 1940 manifests the spirit of liberal parenting, which it assumes was commonly unknown in Turkey. Depicting the previously adopted methods of child training as oppressive, the article, in tandem with the so-called liberating/democratic spirit of the Republic, demands freedom for children to realize themselves:

What a child needs is not oppression but care and understanding. Parents may take pride in a repressed child who has been taught to not talk in front of the adults because she/he appears like a well-mannered, unspoilt child. Yet there is a great chance that this child will grow into a timorous, inept, feckless adult. Up until recently in our society, especially upper-class children used to be raised under strict control and suppressed by unprofessional child-minders, which caused them to become complete failures in their adult life. We might worry about the future of neglected and uncared-for children but there is no need to worry about the future of children who are raised unoppressed. They will turn out just fine. ${ }^{51}$

Two articles by the pedagogue Hasip Aytuna (1895-1980), published in Ülkü in 1948 and 1950, confirm that the pro-regime Turkish intelligentsia's interest in the liberal training of children befitting modern times and modern Turkey retained and reinforced its place in the realm of childhood. The quotations below provide us with a melange of thoughts from Locke through to Rousseau and several Romantics on the education of children, on which modern pedagogy in the early twentieth century had been built:

The mind and soul of a child resemble a blank white slate on which any influence can leave indelible marks. According to psychologists, those marks endured in childhood remain in people's soul and mind throughout

50 Quoted in Fletcher, Growing Up in England, 42.

51 İbrahim Alaettin Gövsa, "Baskısız Çocuklar"[Children Without Oppression], Yedigün, 368, 26 Mart [March], 1940, 14 . 
their lives. Therefore we have to make sure that those childhood marks consist of happiness, love, kindness, fairness and honesty. ${ }^{52}$

Those who are responsible for the education and discipline of children should always refrain from cruel and coercive behaviour towards them, because children are inherently vulnerable, fragile and helpless in all respects. There is nothing worse in the field of education than training and disciplining a child by means of frightening, scolding and beating. Such attitudes invariably cause tension between the tutor and the pupil, turning them into opposite poles. Proper educational practices operate on the basic rule that the tutor should address the natural goodness in the child's soul and manipulate it through compassionate conduct. ${ }^{53}$

Needless to say, we should not assume that these articles, which were devised to inculcate in parents or prospective parents how to treat, love and discipline their children in accordance with the requirements of modern times, would reflect the actual practice of the time. Yet a thorough analysis of this literature can, nevertheless, reveal changing trends as well as the assumed common practices, since this type of advice text usually tends to "correct" their contemporaries' behaviour. Even if we cannot think that the dictates of those texts were observed and followed by all parents, at least we can see what the acceptable treatment of children was in the eyes of the writers of that material; namely, the pro-regime Turkish intelligentsia.

\section{Concluding Remarks}

The articles in this study should be seen as a small sample and popularized version of a much wider professional advice literature mainly composed by pediatricians, pedagogues, psychologists and lawyers during the early decades of the Turkish Republic. They evidence that in the mindset of Turkish intellectuals and policy makers, the 'loving innocence' of Victorian times, along with its all socio-cultural connotations, irrevocably came into play in drawing the borders of and characterizing middle-class childhood. In the broadest sense, however, we can venture to suggest that Turkish children did not acquire particular value in and of themselves through their much-romanticized innocence

\footnotetext{
52 Hasip Aytuna, "Çocuklar ve Büyükler" [Children and Adults], Ülkü, 29, Ekim [October], 1948,11 .

53 Hasip Aytuna, "Çocuklarımız ve Hatalı Terbiyemiz" [Our Children and Our Wrongs in Education], Ülkü, 31, Haziran [June], 1950, 5 .
} 
in the first place. They were rather seen as valuable because of their indispensable status for the success of the new regime. Nevertheless, as their instrumental value increased, the attention they received increased too, which in turn led the Turkish intelligentsia, who had an avowed modernizing agenda, to explore and exploit the discursive elements that fashioned the essential value of the child and childhood in modern Western settings. It should be emphasized, however, that this discursive recognition of childhood innocence did not necessarily translate into official state policies vis-à-vis children. The successive Republican governments persistently avoided, for example, introducing children's courts, a part and parcel of the modern notion of childhood, into the Turkish judicial system until $1979 ;{ }^{54}$ and the Ministry of Education did not see any harm in sponsoring some so-called children's magazines for years whose ultra-nationalistic, indoctrinating content encroached upon supposed childhood innocence with countless horror stories, jingoistic poems and spine-chilling memoirs of war, starvation and exodus. ${ }^{55}$ What is more, during the early decades of the Republic the actual childhood experience of the underprivileged child population, which in fact comprised the majority, was a far cry from the Western-inspired happy and innocent picture of childhood painted in the popular magazines by modernizing intelligentsia. The young regime, with its scarce resources and many other pressing matters to deal with, largely failed to protect the innocence of the majority of its children. An article published in the famous monthly Resimli Ay [Illustrated Monthly] in 1924 by Sabiha Zekeriya, a leftist, feminist journalist and the voluntary attorney of destitute children in the early Republic, speaks volumes. Considering that the conditions depicted by Zekeriya remained unchanged, if not deteriorated in the following decades, well into the post-Second World War period, her article is worth quoting at length for it displays the striking contrast between the actual and the imagined ideal that made up the modern childhood repertoire of the Turkish Republic.

[...] When I saw this man selling his child in a neighbourhood of Istanbul for five hundred Turkish liras as if the child was a commodity I was assured one more time that we are the children of a society that is oblivious to its

54 Nazan Çiçek, "Mapping the Turkish Republican Notion of Childhood and Juvenile Delinquency: The Story of Children's Courts in Turkey, 1940-1990," in Heather Ellis (ed.), Juvenile Delinquency and the Limits of Western Influence, 1850-200o (London: Palgrave Macmillan, 2014), 248-275.

55 Nazan Çiçek, "Erken Cumhuriyet Döneminde Modern Çocukluk Nosyonunun Görünümleri Üzerine Bir Analiz" [An Analysis on the Manifestations of Modern Notion of Childhood in Early Republican Era], Mülkiye Dergisi, 36 (4), 2012, 69-104. 
responsibilities towards children. [...] It is argued that in human societies children are under the protection of family, charitable organizations and the government. Either I do not live in a society or the owners of that assertion are complete liars. Masses of poor, abandoned, orphaned children are begging, stealing and striving to survive in squalid conditions like sinners in every corner of our country. [...] Those who claim that family protects children are lying, because most families do not have the economic means to protect their children. Those who claim that charitable organizations protect children are liars, because if they had, children living as beggars and pick-pockets would not have swarmed the streets of Istanbul. The society which is supposed to spread its protective wings over children abandons them to their fate. Those who claim that the government is protecting children are liars too. If children of a society are left to live without bread, home and morality, then there is no government protection to talk about. If the government does not pass laws for the protection of children in a society where children are sold for money, regularly beaten and frequently killed, then the government protection is a sheer lie. If there are statesmen in a government who sneer at the child issue, denying its importance and contenting themselves with issuing police orders for driving beggars of the streets, then those who claim that the government is protecting children are shamelessly lying. In our society no one, not the family, not the government, is protecting our children. They are born and die like weeds attracting nobody's attention or compassion. ${ }^{56}$

\section{Bibliography}

\section{Primary}

Alaettin Gövsa, İbrahim "Baskısız Çocuklar" [Children Without Oppression], Yedigün, 368, 26 Mart [March], 1940, 14.

Asaf, Burhan, "Çocuk Sevgisi," no date or publication name.

Aytuna, Hasip, “Çocuklar ve Büyükler” [Children and Adults], Ülkü, 29, Ekim [October], 1948, 11.

Aytuna, Hasip, “Çocuklarımız ve Hatalı Terbiyemiz" [Our Children and Our Wrongs in Education], Ülkü, 31, Haziran [June], 1950, 5 .

Bingöl, Cemal, "Çocuk Resimleri ve Yetişkinler" [Children's Drawings and Adults], Ülkü, 26, 1 Ekim [October], 1945, 15-16.

$5^{6}$ Sabiha Zekeriya, "Satılık Çocuk Beş Yüz Lira" [Child for Sale for Five Hundred Liras], Resimli Ay, 4, Mayıs [May], 1340 [1924], 5-7. 
Cevdet, Abdullah, "İngiltere'de Aile Hayatı" [Family Life in England], Süs, 49, 17 Mayıs [May], 1340 [1924], 1.

“Çocuğun ve Annenin Bayramı" [Children's and Mothers' Festival], Yedigün, 59, 25 Nisan [April], 1934, 4.

Cumhuriyet Çocuğu Öğretmeni, "Tarihten Yapraklar, Türk Tarihinde Çocuk," 26, Cumhuriyet Çocuğu, 1938, 473.

Haşim, Ahmet, "Çocuklar İçin Bayram" [Festival for Children], İkdam, 11365, 12 Birincikanun 1928.

Irmak, Sadi, "Çocuk ve Meseleleri" [Child and the Child Question], Ülkü Halk Evleri Mecmuası, 23, 1944, 3.

"İstismar Edilen Çocuk," [The Child that is Abused] Gürbüz Türk Çocuğu, 43, Nisan [April]. 1930, 7 .

"İyi Bir Anne misiniz?" [Are you a Good Mother?], Ev-İs, Nisan [April], 1949, 43.

K.A., "Çocuklarımız Gazete Okumalı mı? Etfalin Terbiye-i Ruhaniyesi" [Should Our Children Read Newspapers? Psychological Training of our Small Children], Asar-ı Nisvan, 8, Haziran [June] 1, 1341 [1925], 6-7.

Kayacan, Selami İzzet, “Çocuk” [The Child], Yedigün, 111, 24 Nisan, 1935, 14-15.

Tuğcu, K., “Çocuk Terbiyesi: Büyükler ve Küçükler” [Children's Education: Adults and Kids] Ev-Iss, Temmuz [July], 1942, 68.

Yalçın, Hüseyin Cahit, “Çocuk Haftası” [Children’s Week], Yedigün, 24 Nisan 1935 (111), 4. Zekeriya, Sabiha, "Satılık Çocuk Beş Yüz Lira" [Child for Sale for Five Hundred Liras], Resimli Ay, 4, Mayıs [May], 1340 [1924], 5-7.

\section{Secondary}

Akın, Yiğit, Ana Hatları ile Cumhuriyet Döneminde Beden Terbiyesi ve Spor [Physical Education and Sports in the Early Republican Era], İstanbul: İletişim, 2004.

Ambert, Anne-Marie, "An International Perspective on Parenting: Social Change and

Social Constructs," Journal of Marriage and Family, 56, 1994, 529-543.

Ariès, Philippe, A Social History of Family Life, London: Jonathan Cape, 1962.

Behnke Kinney, Anne, Representations of Childhood and Youth in Early China, Stanford: Stanford University Press, 2004.

Çiçek, Nazan, "Erken Cumhuriyet Döneminde Modern Çocukluk Nosyonunun Görünümleri Üzerine Bir Analiz" [An Analysis on the Manifestations of Modern Notion of Childhood in Early Republican Era], Mülkiye Dergisi, 36 (4), 2012, 69-104. Çiçek, Nazan, "Mapping the Turkish Republican Notion of Childhood and Juvenile

Delinquency: The Story of Children's Courts in Turkey, 1940-1990," in Heather Ellis (ed.), Juvenile Delinquency and the Limits of Western Influence, 1850-2000, London: Palgrave Macmillan, 2014, 248-275.

Cunningham, Hugh, Children and Childhood in Western Society Since 150o, London: Longman, 1995. 
Emiroğlu, Öztürk, Tanzimattan 1928'e kadar Yayımlanan Çocuk Gazete ve Dergileri Üzerine Bir Inceleme [An Examination of the Children's Newspapers and Magazines Published Between the Tanzimat and 1928], unpublished MA Thesis, Erciyes Üniversitesi, Kayseri, 1992.

Enginün, İnci and Zeynep Kerman (eds), Ahmet Haşim: Bütün Eserleri II, İstanbul: Dergâh Yayınları, 1991.

Ersoy, Erhan G., "1930'ların Kültür ve Eğitim Anlayışının Çocuk Esirgeme Kurumu Neşriyatı Çocuk Dergisindeki Yansımaları," [The Reflections of 193os Cultural and Educational Perceptions in the Children's Protection Society] Kebikeç 19, 2005, $373-387$.

Ertem, Özge, The Republic's Children and Their Burdens in 193os and 1940s Turkey: The Idealized Middle-Class Children as the Future of the Nation and the Image of 'Poor' Children in Children's Periodicals, unpublished MA Thesis, Bosporus University, İstanbul, 2005.

Fletcher, Anthony, Growing Up in England: The Experience of Childhood 1600-1914, New Haven: Yale University Press, 2008.

Gencer, Yasemin, "We Are Family: The Child and Modern Nationhood in Early Turkish Republican Cartoons (1923-28)," Comparative Studies of South Asia, Africa and the Middle East, 32 (2), 2012, 294-309.

Göral, Özgür Sevgi, The Child Question and Juvenile Delinquency During the Early Republican Era, unpublished MA Thesis, Boğaziçi University, İstanbul, 2003.

Gürkan Öztan, Güven, Türkiye'de Çocukluğun Politik İnşası [Political Construction of Childhood in Turkey], İstanbul: İstanbul Bilgi Üniversitesi Yayınları, 2011.

Hendrick, Harry, Childhood and English Society, 1880-1990, Cambridge: Cambridge University Press, 1997.

İnanç Özekmekçi, Mehmet, The Formation of Children in the Late Ottoman Empire: An Analysis Through the Periodicals for Children (1869-1914), unpublished MA Thesis, Boğaziçi University, İstanbul, 2005.

Jenks, Chris, Childhood, London: Routledge, 1996.

Kandiyoti, Deniz, "Gendering the Modern: On Missing Dimensions in the Study of Turkish Modernity," in Sibel Bozdoğan and Reşat Kasaba (eds), Rethinking Modernity and National Identity in Turkey, Seattle: University of Washington Press, 1997, $113^{-131 .}$

Karimi, Pamela and Christiane Gruber, "Introduction: The Politics and Poetics of the Child Image in Muslim Contexts," Comparative Studies of South Asia, Africa and the Middle East, 32 (2), 2012, 273-293.

Kessen, William, Psychological Development from Infancy: Image to Intention, New York: Wiley, 1979 .

Libal, Kathryn, “The Children's Protection Society: Nationalizing Child Welfare in Early Republican Turkey," New Perspectives on Turkey, 23, 2000, 53-78. 
MacLeod, Anne Scott, American Childhood: Essays on Children's Literature on the Nineteenth and Twentieth Centuries, Athens: University of Georgia Press, 1994, 99.

Meyer, Anneke, "The Moral Rhetoric of Childhood," Childhood, 14 (1), 2007, 85-104.

Ndebele, Njabulo, "Recovering Childhood: Children in South African National Reconstruction," in Sharon Stephens (ed.), Children and the Politics of Culture, Princeton: Princeton University Press, 1995, 321-333.

Neyzi, Leyla, “Object or Subject? The Paradox of 'Youth' in Turkey," International Journal of Middle East Studies, 33 (3), 2001, 411-432.

Okay, Cüneyd, CemiyetiBelgelerle Himaye-i Etfal 1917-1923 [Himaye-i Etfal and the Related Documents 1917-1923], İstanbul: Şule Yayınları, 1999.

Okay, Cüneyd, Meşrutiyet Çocukları [Children of Constitutional Era], İstanbul, Bordo, 2000.

Okay, Cüneyd, YenileşmelerOsmanlı Çocuk Hayatında 1850-190o [Novelties in the Life of Ottoman Children 1850-190o], İstanbul: Kırkambar Yayınları, 1998.

Özman, Aylin, "Domesticated Souls: Vâlâ Nureddin (Vâ-Nû) on Womanhood," Turkish Studies, 8 (1), 2007, 137-150.

Öztamur, Pınar, Defining a Population: Women and Children in Early Republican Turkey 1923-1950, unpublished MA Thesis, Bosphorus University, İstanbul, 2004.

Pease, Catherine E., "Remembering the Taste of Melons: Modern Chinese Stories of Childhood," in Anne Behnke Kinney (ed.) Chinese Views of Childhood, Honolulu: University of Hawai'i Press, 1995.

Prout, Alan and Allison James, "A New Paradigm for the Sociology of Childhood? Provenance, Promise and Problems," in id. (eds), Constructing and Reconstructing Childhood, London: Routledge, 1990, 7-33.

Şahin, Mustafa “23 Nisan ve Himaye-i Etfal,” [April 23 and Children's Protection Society] Toplumsal Tarih, Nisan [April], 1997 (40), 15-17.

Stearns, Peter N., Childhood in World History, London: Routledge, 2006.

Steedman, Carolyn, Childhood, Culture and Class in Britain:Margaret McMillan 1860-1931, London: Virago, 1990.

Toprak, Zafer, “İkinci Meşrutiyet Döneminde Paramiliter Gençlik Örgütleri”[Paramilitary Youth Organizations in the Second Constitution Period], in Tanzimattan Cumhuriyete Türkiye Ansiklopedisi, İstanbul: İletişim Yayınları, 1985, 531-536.

Üstel, Füsun, Makbul Vatandaşın Peşinde: II. Meşrutiyetten Bugüne Vatandaşlık Eğitimi [In Quest of the Acceptable Citizen: Citizenship Education Since the Second Constitutional Era], İstanbul: İletişim, 2004.

Zelizer, Viviana A., Pricing the Priceless Child: The Changing Social Value of Children, Princeton: Princeton University Press, 1985. 